\title{
IMPROVING FUNCTIONAL TEXT WRITING ACHIEVEMENT BY USING FOUR SQUARE STRATEGY AT SMK NEGERI 2 SEKAYU
}

\author{
By: \\ Irlina \\ SMK Negeri 2 Sekayu, South Sumatera \\ e4rly3@gmail.com
}

\begin{abstract}
The fact that English writing skill in Indonesia is still low encouraged the writer to conduct this study concerning vocational high school students. Four Square strategies in prewriting activities help students to write, especially in writing functional text. The objective of this study was to see if there was a substantial difference in writing achievement between students who were taught with the Four Square strategy and those who were not. The quasiexperimental approach was applied in this research. The population of SMK Negeri 2 Sekayu's eleventh graders in the academic year 2021/2022 with a total of 217 students. From this group, 60 students were chosen as the sample and divided evenly into two groups, the experimental and control groups. The Four Square strategy was used to teach the experimental group, whereas the control group received no treatment. However, all the students in the two groups were given writing tests before and after the application of the two strategies. A t-test was used to assess the data collected. The result showed that the experimental group outperformed the control group with a significant mean difference of $23.82(\mathrm{p}<0.00)$. These results indicated that the Four Square strategy was effective in improving the students' writing achievement.
\end{abstract}

Keywords: four square, functional texts, writing achievement

\section{INTRODUCTION}

As one of the four language skills, writing is just as vital as the other three. As supported Sartika \& Arriyani (2020), students who acquire writing abilities can use written communication to express information, thoughts, experiences, or ideas with others.
Without writing there will be much information that cannot be kept and will be lost.

Nevertheless, writing may be considered as a complicated skill to master among the four language skills. In a writing activity, students should have an idea, organize it into a good organization by using relevant 
vocabulary and good grammar. Besides, appropriate mechanics, for example, spelling, punctuation, and capitalization is needed. Because of these aspects, writing becomes a challenging task for students and often makes them frustrated (Kartika, 2013).

Writing English is difficult for learners to master as it is a foreign language with rules that differ from those learned in the first language, and it necessitates the use of numerous writing components such as punctuation, spelling, and capitalization (Sartika and Nery, 2018). The difficulties in writing can influence students' ability in writing, especially in English. Writing in English means that a student has to work harder because they should think about how to develop their ideas by using some elements in writing such as appropriate vocabulary, correct grammar, and clarity of information so that readers can get the message.

Based on the researcher's experience teaching writing at SMK Negeri 2 Sekayu, almost all students complained when doing writing activities because they did not know how to find ideas, develop the ideas into a written message, and use appropriate vocabulary and grammar. As a result, students' writing achievement becomes low. Whereas, writing should be implemented in most students learning activities because the current curriculum requires students to implement High Order Thinking Skill (HOTS), and one of the HOTS activities in learning language is writing.

Even though writing is considered a very difficult activity to do for students, it must still be taught at schools. Like other skills, writing plays an important role in the students' language learning. When English 
learners can write well, they will be able to speak well and promote reading ability more effectively (Anh, 2019).

From the description above, it is worth saying that to help increase the motivation to write, writing can be started at school. An English teacher needs to find out an interesting and a helpful strategy that could be applied in teaching writing.

Many strategies can be used in teaching writing. Four Square is one of the strategies which can be applied to help students who get difficulties to start writing. According to Rofi'ah and Ma'rifah (2017), Four Square can be used to activate and arrange the students' schema, which helps them produce a text. They also stated that teaching narrative writing with Four Square through image series is highly recommended.

In addition, Four Square is a set of procedures that can help students grasp how to arrange their writing correctly and can be utilized in collaborative learning activities (Yunus, Dollah, and Munir, 2021). The procedures include how to identify the relationship, label the topic phrase, provide explicit facts, compose a paragraph, summarize the material, and include essential transitional words to make the text cohesive and coherent.

Furthermore, Puspita argues that Four Square Writing is a writing approach that helps students improve, connect, and arrange their ideas. Four Square also assists learners in combining and generalizing the greatest outline, data, and concepts (Agustiana, 2017).

Besides, Four Square uses graphic organizers which consist of four outside squares (Ilmiah et al., 2017). The center square is where the topic is put. The other three outside squares are for the supporting ideas. Lastly, the final 
square is for conclusion statements. In

other words, the students start writing with their main topic, then, in each square, build their supportive sentences, and finally conclude their writing. The visual and kinesthetic aid help students to focus on their writing, provide details, and enhance word choice (Zahara, 2017).

For vocational school students, the writing is mostly focused on functional texts. Therefore, in this study, functional texts as the teaching and learning material were used. Functional text is called so because it has specific information. According to Cameron \& Myers (2013), a functional text is one that is written to provide specific information to the reader or to assist the reader in performing a daily job.

Badyra (2011) also state that functional text is a specific text which contains a command, direction, instruction, such as an invitation, a short message, a shopping list, an announcement, and others that are meaningful and used for daily communication. That is why, functional texts are considered appropriate for vocational students' needs, both during their study and in the workplace later.

The goal of this study, based on the preceding description, was to see if there was a substantial difference in writing achievement between students who were taught using the Four Square strategy and those who were not.

\section{METHODOLOGY}

In this study, a quasi-experimental design was utilized. The population of this study was all the eleventh-grade students of SMK Negeri 2 Sekayu in academic year 2021/2022. The sample was selected using a purposive sampling method. The criteria of a sample were based on their English 
achievement; that was, those whose average score was between 55 and 75 . Based on the score, the writer divided them into three categories: good (6975), average (62-68), and low (55-61). To make fair, the writer spread out the students on each category into experimental and control groups.

In this study, the experimental group got the treatment using the Four Square strategy. The procedures of teaching writing by using the Four Square strategy are as follows:

1) Explain some kinds of functional texts, like a memo, a personal letter, an invitation, an advertisement, and so forth.

2) Explain the format of the Four Square related to the topic.

3) Give an example of how to write by using the Four Square strategy

4) Ask students to write a kind of functional text based on the topic given.
5) Ask students to write their works on the whiteboard.

6) Discuss the students' work and give comments.

The data were collected using a writing test. The writer asked the sample to write an invitation based on the situation given. The validity of the test was estimated using content validity. The writer estimated the content validity by drawing up a table of specifications based on the English syllabus. Moreover, the writer used the inter-rater method to ensure that the students' writing was reliable. As a result, two raters who met the writer's qualifications evaluated the students' writing scores. The two raters used rubrics to grade the students' writing. To estimate a reliability of the test, Cronbach Alpa was used. 


\section{RESULT AND DISCUSSION}

Based on the result of the pretest

of the experimental group, the lowest score was 29.50 , the highest score was 60.80 , and the mean was 45.97 . For the control group, in the pretest, the lowest score was 30.50 , the highest score was 62.60, and the mean was 43.89. The result of the posttest showed the lowest score for the experimental group was 54.40 , the highest score was 82.60 , the mean was 69.79 . For the control group, the lowest score was 34.50, and the highest score was 65.70, and the mean was 48.82 (See Table 1).

Table 1.

The Results of the Pretest and Posttest of Experimental and Control Groups

\begin{tabular}{lcccc}
\hline \multirow{3}{*}{ Groups } & \multicolumn{2}{c}{ Pretest } & \multicolumn{2}{c}{ Posttest } \\
\cline { 2 - 5 } & Lowest & Highest & Lowest & Highest \\
& Score & Score & Score & Score \\
\hline Exp. & 29.50 & 60.80 & 54.40 & 82.60 \\
Con. & 30.50 & 62.60 & 34.50 & 65.70 \\
\hline
\end{tabular}

Based on the results of the independent sample t-test, in the experimental group, the mean of the pretest was 45.97, the mean of the posttest was 69.79 , the mean difference between the posttest and the pretest was 23.82, and the p-value was 0.00 . Since p-value (0.00) was lower than avalue (0.05), so it was confirmed that teaching writing through the Four Square strategy effectively increased the students' writing achievement.

Meanwhile, in the control group, the mean of the pretest was 43.89 , the mean of the posttest was 48.82, the mean difference between the posttest was 4.93 , and p-value was 0.85 . Since p-value (0.085) was higher than $\alpha$-value (0.05), so it was inferred that the writing achievement of the students in the control group did not increase significantly (See Table 2).

Table 2

The Results of Independent Sample t-test

\begin{tabular}{lllll}
\hline \multirow{2}{*}{ Groups } & \multicolumn{2}{c}{ Mean } & \multicolumn{2}{c}{ Mean } \\
\cline { 2 - 3 } & Pretest & Posttest & Difference & Sig. \\
\hline Exp. & 45.97 & 69.79 & 23.82000 & 0.000 \\
Con. & 43.89 & 48.82 & 4.93500 & 0.085 \\
\hline
\end{tabular}

The finding showed evidence that the students' writing achievement increased, though it was not very 
satisfactory because the mean of the writing posttest in the experimental and control groups was only 61.83. Based on the level of achievement, no student reached the Excellent level.

However, $70 \%$ of the students belonged to good and average levels. The acceptable explanation for this condition was that the students were still having difficulty composing words and sentences into good writing, as most of the learners had limited vocabulary, grammar, and prior knowledge, according to the writer's teaching experience in the school. These were most likely the roadblocks to them writing good compositions, particularly functional texts.

Next, the finding showed evidence that there was a significant difference in the results of the posttest between the experimental group and the control group. It can be inferred that the use of Four Square could help the students to organize their thoughts logically since this method emphasizes the students' unity on a topic sentence, supporting details, and then wrap up a sentence.

The result of this study was in line with Lestari (2011) who found that students' writing skills were improved utilizing the Four Square writing approach, which included writing to explore their ideas, writing a paragraph using perfect grammar, employing vocabularies, writing paragraphs clearly and cohesively, and using word order and punctuation in writing sentences. Ferawati (2019) reported that writing in four squares increased students' ability to write. The students stated that the Four Square Method to be a useful strategy for learning and teaching English (Muth'im and Norhasanah, 2018).

In short, Four Square helped learners improve their writing skills so 
that they could write functional text by following Four Square format.

\section{CONCLUSION}

The Four Square strategy was efficient in helping students improve their writing skills. The study's findings revealed a substantial difference in writing achievement between students taught with Four Square and those who were not. It is because after using the Four Square strategy, learners were able to write more functional texts. Using Four Square as the prewriting instructions, the students' challenges with initiating and developing their thoughts were solved. Students used the Four Square writing organizer to arrange their thoughts and add specifics to their writing. In other words, learners know what they need to write because they have already completed the drafts in the four spaces provided. Furthermore, the Four Square strategy's rules can help students express themselves clearly and simply while remaining focused on a topic.

\section{REFERENCES}

Agustiana, V. (2017). Four Square

Writing Method applied in product and process based approaches combination to teaching writing discussion text. English Review: Journal of English Education, 6(1), 89. https://doi.org/10.25134/erjee.v6i1. 774

Anh, D. (2019). EFL Student's Writing Skills : Challenges and Remedies. IOSR Journal of Research \& Method in Education, 9(6), 74-84. https://doi.org/10.9790/73880906017484

Badyra, N. (2011). Teks fungsional pendek.Retrived from http://nurulbadrya.blogspot.com/20 11/10/teks-fungsional-pendek.html 
Cameron, S., \& Myers, S. (2013).

Comprehending functional text:

Instruction, practice, assessment.

Mark Twain Media, Inc.

Ferawati, J. (2019). Investigating the influence of the Four-Square writing method on year 8 students' narrative writing skills in English as a second language. Jurnal Ilmiah Maksitek, 4(2), 5.

https://makarioz.sciencemakarioz.o rg/index.php/JIM/article/view/83/8 0

Ilmiah, Supardin, Latief, H., \& Basri, M. (2017). Improving the students' ability to write descriptive texts through Four Square writing method. Exposure Journal, 6(1), 82-96.

Kartika. (2013). The effect of four square method toward the eight grade students' ability at 11 SMP 1 in writing descriptive text. Unpublished: Jambi University.
Retrived from http://fkipunjaok.com/versi_2a/extensi/artikel_il miah/artikel/A1B208007_492.pdf

Lestari, E. S. (2011). Improving the students' writing skill by using four square writing method. Unpublished: University Sebelas Maret of Surakarta.

Muth'im, A., \& Norhasanah. (2018). Four Square writing method as a technique to teach descriptive writing. JEELS, 5(2), 259-277. Puspita, N. (2015). The effectiveness of four square writing in teaching writing viewed from students' creativity. Jurnal Tadris Bahasa Inggris, 7(1), 64-80.

Rofi'ah, A., \& Ma'rifah, U. (2017). The effect of Four Square Writing Method ( FSWM ) through picture series in writing narrative text for eleventh grade at SMA Nusantara Balongpanggang. Journal of English Teaching, Literature, and 
Applied Linguistics, 1(2), 50-61.

Muhammadiyah Sumatera Utara.

Sartika, D., \& Arriyani, N. (2020).

Enhancing students writing skill to

write descriptive text using peer

review and free writing techniques.

English Community Journal

(2020), 4(2), 90-97.

Sartika, D., \& Nery, R. (2018). The

effect of PLEASE strategy and

writing interest toward students'

writing skill. Journal of English

Education and Linguistics, 2(1),

$20-32$.

Yunus, Y., Dollah, S., \& Munir. (2021).

The use of Four-Square technique

to improve students' writing

ability. Tamaddun Life: Jurnal

Bahasa, Sastra Dan Budaya,

20(1), 1-14.

Zahara, F. (2017). The effect of four

square writing method (FSWM) on

students' achievement in writing

descriptive paragraph.

Unpublished: University of 